\title{
High-titer RSV Immune Globulin RI-001
}

National Cancer Institute

\section{Source}

National Cancer Institute. High-titer RSV Immune Globulin RI-001. NCI Thesaurus. Code C103866.

A plasma-derived, polyclonal, intravenous immunog lobulin formulation (IVIG) containing standardized high levels of antibodies against respiratory syncytial virus (RSV), a singlestranded, enveloped paramyxovirus, with potential immunomodulating activity. The hightiter RSV immune globulin RI-001 is derived from healthy donors with high amounts of RSV antibodies. Upon intravenous administration, the antibodies against RSV may provide passive immunization against RSV. This may prevent lower respiratory tract infections by RSV in immunocompromised patients. The polyclonal antibodies in RI-001 are able to target various viral epitopes. 